now widely used. As in previous colloquia, oach formal paper is followed by a transcription of the informal discussion among the twenty-two conference members. These sections of the book provide stimulating reading.

The papers can be divided roughly into several groups: those devoted mainly to morphology include a study of its relation to external genitalia and phenotypo in man, by J. E. Jirásek; the morphological changes throughout foetal development and their relation to enzymes involved in synthesizing and metabolizing steroid hormones, by $\mathrm{M}$. Niemi; and a multifaceted study by E. Steinberger of Leydig cells in culturc. Aspects of steroid biosynthesis by the testis are covered in another group of papers. R. I. Dorfman presented reaction sequences obsorved in various species; H. Inano showed the changes in the pertinent enzymes of rat testes with age; L. T. Samuels described the effects of oestrogens on the enzymes synthesizing testosterone in the testes of mice; and $\mathrm{K}$. EikNes summarized recont experiments on factors influencing the secretion of tostosterone and other storoids in the dog, as determined by analyses of spermatic vein blood.

Most of the other papers are clinically oriented in that they deal with evaluation of testicular function in the human male and its control and variations, both abnormal and normal. B. Hudson emphasizes how much has beon learned (and is still to be learned) from the ultramicroanalytical methods recently developed for measuring testosterone and other androgens in plasma. J. K. Grant reviewed the work of his and other laboratorios on the often baffling relationships of clinical abnormalities (such as the syndrome of testicular feminization) to inberent defects in steroid biosynthesis. F. A. de la Balze described observations in patients with testicular dysgenesis. Lastly, the paper by L. M. Fishman concerns the production of oestrogens by the testis, and describes combinations of isotopic and chromatographic analyses of blood and urine following intravenous infusion of tracers, showing the importance of steroid interconversions and conjugation in evaluating low levels of oestrogen production.

Other papers deal with the effect of hormones on spermatogenesis, on degeneration of an ischaemic testis, on the composition of semen, and on the embryo gonaducts. The final pages give a most interesting general discussion among the conference members.

This volume, dedicated to the memory of Dr Warren O. Nelson, is beautifully edited, and indeed does honour to that pioneer contributor to the field.

H. N. WIISON

\section{COMPANY OF TWO}

\section{Twins and Twin Relations}

By Helen L. Koch. Pp. xvi +302 . (Chicago and London: The University of Chicago Press, 1966.) $\$ 6.95 ; 528$.

Twins were at one time little more than pawns in the nature-nurture controversy, but they are now being studied in their own right, and psychologists and other behavioural scientists are beginning to concern themsolves in detail with tho special biological and social phenomena which they present. They are known to undergo considerable prenatal and noonatal hazards, especially prematurity and dysmaturity, and to have a neonatal mortality rate seven times that of singletons. Tho intellectual and linguistic retardation found in twin popula tions, however, cannot be ascribed entirely to the minimal neurological disorders which might result from such hazards, but may in part be a result of the unique psycho. social phenomena presented by twins; their close relationship (especially MZ pairs) has been hold responsible for a measure of isolation from their environment.

Helen Koch's study concerns itself with both biological and social questions; it focuses on nincty pairs of twins between five and six years old, equally divided by sex and zygosity, all first-born, only children in their white, urban families. Control groups of singletons wero carefully matchod - as many as four singletons for each pair on many comparisons. Subjects were recruited by schools. Although her twins are far from representative of the twin population as a whole, the group is homogeneous on a number of critical variables-a factor which would tend to reduce the size of correlations, but has the advantage of holding ago constant. Dr Koch has little new to report on the biological side, but provides some useful data on the relationship of twins to one another and to their peers; her data suggest that they are on the whole more popular among their classmates (especially MZ girls) than matched singleton controls. Scores on the primary mental abilities test were slightly below those of controls, especially in the case of MZ boys, and even more marked deficits were seen on a number of somewhat crude assessments of linguistic competence. Here again, it is difficult to know whethor the linguistic impairments are related to a prematurity factor (for premature singletons also show mild cognitive and linguistic deficits as late as eleven years), to tho poor speech model which twins present to one another, or to their relative isolation from adult speech models.

The book also presents detailod findings on hand preferonce and stuttering, on personality and attitudes and on sex differences; raw data can bo studied in eighty pages of appendices. Statistical treatment is exhaustively and meticulously carried out, usually by a three way analysis of variance. In presenting hundreds of intercorrolations among a very large number of variables, however, the data are limited by the fact that a proportion of the correlations are likely to be significant by chance, and are in any case reduced in size by the homogencity of the sample. Dr Koch's interest in twins is clearly intense (her mother was a twin) and she raises numerous important questions, only a few of which are even tackled by her research. It is all the more surprising, therofore, to find so few references to some of the major Furopean twin studies, most of which are directly relevant to her work. Luria, Zaz\%o, Husén, Lehtovaara and Blewett, to name just a few, are not mentioned; even Burt is only referred to in connexion with his work on left-handedness. Studies of twins in school are now fairly numerous, and well reviewed, and it is a pity that there is little attempt in this book to take the opportunity of relating its important findings to the literature as a whole. On the other hand, Dr Koch is clearly more familiar with the biological literature than many psychologists, and performs a useful service by reviewing obstetric and paediatric studies of twins. As for the psychology of twins, we still have much to learn.

P. J. Mittler

\section{AWAIT THE INEVITABLE HOUR}

\section{The Deer and the Tiger}

A Study of Wildlife in India. By George B. Schaller. Pp. of California Press; London: Cambridge University of Chicago Press, 1967.) $\$ 10 ; 72 s$. net.

The Galápagos

Edited by Robert I. Bowman. (Proceedings of the Sym posia of the Galápagos International Scientific Project.) Pp. xvii +318 . (Borkeloy and Los Angeles: University of California Press; London: Cambridge University Press, 1966.) $\$ 10 ; 80 s$. net.

Bотн these books are about conservation. The Galápagos Islands are well known as an archipelago of great biological interest in which the fora and fauna havo suffered serious devastation at the hands of man. In particular their giant tortoises have been ruthlessly used for provisioning ships-of the early explorers and "privateers", and of the 